901

\title{
粒子群を含む流れのカオス的挙動に関する数值的研究
}

\section{Numerical simulation on the chaotic behavior of a flow containing particles}

\author{
○学 新庄 弘明（岡山大院），正 柳瀬 真一郎（岡山大院），正 河内 俊憲（岡山大院）
}

Hiroaki SHINJO, Okayama University, 3-1-1 Tsushimanaka, Okayama kita-ku, Okayama, 700-8530 Japan

Shinichiro YANASE, Okayama University, 3-1-1 Tsushimanaka, Okayama kita-ku, Okayama, 700-8530 Japan

Toshinori KOUCHI, Okayama University, 3-1-1 Tsushimanaka, Okayama kita-ku, Okayama, 700-8530 Japan

Key Words. Particle-laden Flow, Duct Flow, Direct Numerical Simulation, Force Coupling Method, Chaotic

1. 諸言

流体の状態制御は工学的に大変重要な分野である. その中 でも, 流れから受ける抵抗を低減するための研究は大いに有 用なものである．なぜなら，船舶に代表されるように，流体 と接するものを運搬するという要求はいたるところにある. そのため, 摩擦抵抗低減によるエネルギーコスト削減のメリ ットは, 数多くの場で得られるからである.

現在, 摩擦抵抗低減のため表面形状を工夫したり，流体に 添加剤を入れたりと様々な手法がとられている.しかし，表 面形状は微細な傷で変化しうるため, 保守性もまた考えなけ ればならない．また，添加剤については，環境污染への十分 な対処を求められる.

ここで, 摩擦抵抗低減方法にマイクロバブルを用いたもの がある(1)。これは船には実際に使われている方法なのである が，微小な気泡を使うだけなので，保守性や環境污染を気に する必要がなくなる．だが，実際にマイクロバブルがどう作 用して，低減効果を発生させているのかは解明されていない． そのメカニズム解明には, 物理実験のみでは限界があり, 数 值解析による手法も必要とされる.

そこで本研究では, 粒子の摩擦低隇メカニズム解明の一助 として, 流れに乱れを生じさせた直管内流れに粒子群を付加 し, 直接法による数值計算を行い, 元のカオス的挙動を示す 流れからの挙動の変化を調べた.

粒子の計算には, 粒子周りに厳密な境界条件を課す代わり に，Force Coupling Method(2)を用いた方法をとる.この手法 は粒子を剛体と考え，それによる流れの影響を，粒子にかか る力とモーメントの影響を周囲流体に重み付けをして与え るものである．前者は Force Monopole，後者は Force Dipole と名付けられている。

\section{2. 基礎方程式}

本研究では，粒子群を含む直管内流れを想定する．この流 れには周期性があるものとし，管壁ではすべりが起きず，あ る圧力勾配を持つものとしている．計算領域は，直管縦幅を 代表長さとし，(横幅)/(縦幅)をアスペクト比 $A_{\mathrm{s}}$ で表し，流 れの周期は $L$ としいる. また，xyz 軸はそれぞれ周期方向， 縦幅方向, 横幅方向にとる. 計算モデルに粒子を付加したと きの様子を図 1 に示す.

使用される方程式は，直管横幅，代表速度，流体密度で無 次元化を行った.まず，ナビエ・ストークス方程式は次のよ うに表される.

$$
\frac{\partial u}{\partial t}=-\nabla \cdot(u u)-\nabla P+\frac{1}{R e} \nabla^{2} u+g+f_{\mathrm{p}}
$$

なお，式中の記号の意味は次に示すとおりである.

$\begin{array}{lr}\text { 速度: } \boldsymbol{u} & \text { レイノルズ数: } R e \\ \text { 圧力: } P & \text { 重力加速度ベクトル: } g \\ \text { 時刻: } t & \text { 粒子からの体積力: } \boldsymbol{f}_{\mathrm{p}}\end{array}$

この中で最後の項は Force Coupling Methodによる粒子に よる影響力の項であり，

$$
f_{\mathrm{p}_{\mathrm{i}}(\boldsymbol{x}, t)}=\sum_{\mathrm{n}=1}^{\mathrm{N}} F_{\mathrm{i}_{(t)}}^{(\mathrm{n})} \Delta_{\left(\boldsymbol{x}-\boldsymbol{Y}_{(t)}^{(\mathrm{n})}, \sigma_{\mathrm{m}}^{(\mathrm{n})}\right)}^{(\mathrm{n})}+\sum_{\mathrm{n}=1}^{\mathrm{N}} G_{i j}^{(\mathrm{n})} \frac{\partial}{\partial x_{j}} \Delta_{\left(\boldsymbol{x}-Y_{(t)}^{(\mathrm{n})}, \sigma_{\mathrm{d}}^{(\mathrm{n})}\right)}^{(\mathrm{n})}
$$

と表される.ここで, 第 1 項は Force Monopole を, 第 2 項 は Force Dipole である.この式は，各粒子が本来受けるはず の力 $\boldsymbol{F}^{(\mathrm{n})}$ をガウス関数 $\Delta^{(\mathrm{n})}$ による重み付けをすることで, 粒 子の影響を粒子周辺の流体に与える外力で近似を行ったも のである.なお， $\boldsymbol{Y}^{(\mathrm{n})}$ は粒子の位置べクトル， $\mathrm{N}$ は粒子の数 であり， $\sigma_{\mathrm{m}}^{(\mathrm{n})}, \sigma_{\mathrm{d}}^{(\mathrm{n})}$ は粒子に厳密な境界条件を課したときの数 值計算と一致するように調整された長さのパラメータであ る(3)(4).

$\boldsymbol{F}^{(\mathrm{n})}$ は加速度系から見た浮力による力と, 壁面及び粒子同 士の反発力 $\boldsymbol{F}_{\mathrm{c}}^{(\mathrm{n})}$ を導入すると次のように表せる(5).

$$
\boldsymbol{F}^{(\mathrm{n})}=\frac{4}{3} \pi\left(r_{\mathrm{a}}^{(\mathrm{n})}\right)^{3}\left(r_{\mathrm{p}}-1\right)\left(\boldsymbol{g}-\frac{d \boldsymbol{V}^{(\mathrm{n})}}{d t}\right)+\boldsymbol{F}_{\mathrm{c}}^{(\mathrm{n})}
$$

ここで, $r_{\mathrm{a}}^{(\mathrm{n})}$ は直管横幅と比べての粒子半径， $r_{\mathrm{p}}$ は粒子密度 を流体密度と比べての比重である．また， $\boldsymbol{F}_{c}^{(\mathrm{n})}$ は粒子にかか る反発力であり，粒子と壁や粒子同士の位置関係により，互

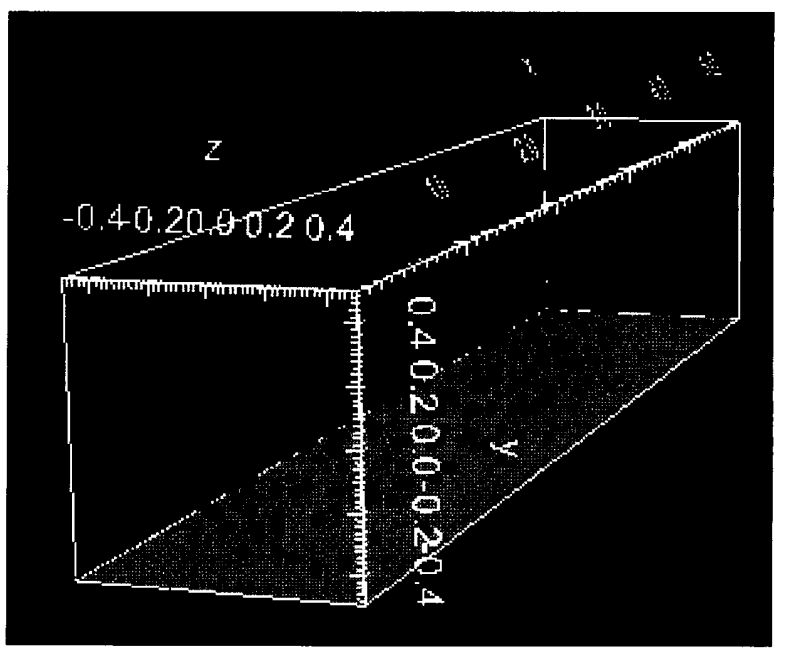

Figure 1 simulation model 
いに重なり合うのを防ぐため，適当な大きさを加える.

そして粒子の速度は, 粒子周囲の速度にガウス関数型の重 み付けを施した積分により求める。

$$
\boldsymbol{V}_{(t)}^{(\mathrm{n})}=\int \boldsymbol{u}_{(\boldsymbol{x}, t)} \Delta_{\left(x-\mathbf{Y}_{(t)}^{(\mathrm{n})}\right)}^{(\mathrm{n})} d \mathrm{~V}
$$

$G_{\mathrm{ij}}^{(\mathrm{n})}$ は粒子の回転モーメント表す非対称成分 $T_{\mathrm{ij}}^{(\mathrm{n})}$ と変形に 対する抗力のモーメントを表す対称成分 $S_{\mathrm{ij}}^{(\mathrm{n})}$ とに分けられる. 特に $S_{\mathrm{ij}}^{(\mathrm{n})}$ は粒子の剛性に関する条件から，反復法により計算 する必要がある(6)

\section{3. 計算手順}

計算に使用する格子は $\mathrm{y}, \mathrm{z}$ 方向を壁面に近づくにつれ格 子間隔が狭まるように, 不等間隔な形状のスタッガード格子 を用いる. 微分や補間の式は 4 点を用いた差分式で表す.

各方程式の解き方を以下に示す．まず，時刻 $t$ での粒子の 位置情報，加速度情報から $\boldsymbol{F}^{(\mathrm{n})}$ を求める。ここで，加速度は 過去の 2 つの粒子速度を用いて次のように表す。

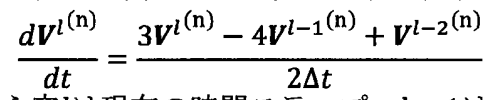

なお，上添え字lは現在の時間ステップ, $l-1$ は 1 つ前の時 間ステップを表す。これから，粒子の作用 $\boldsymbol{f}_{\mathrm{p}}$ を計算する。 た だし、初期の加速度計算のため、 $\boldsymbol{V}^{-1}=V^{-2}=V^{0}$ と定常運動 をしていたとしている.

$T_{\mathrm{ij}}^{(\mathrm{n})}$ を求めるのにも同様な計算が必要となるが，初期条件 は定常の回転運動をしていたとしている.

次にナビエ・ストークス方程式を解く．そのための時間進 行法は, 移流項にはアダムス・バッシュフォース法（初期ス テップのみオイラー法), 粘性項にはクランク・ニコルソン 法を用い，SMAC 法で解く．また，4つの微分方程式が出て くるが，す心゙て差分式に詨し， $\mathrm{x}$ 方向の離散フーリエ変換を 行い(7), ILU(0)分解を前処理行列とした両側前処理を施し, BiCGStab 法を用いる(8)

そうして求められた次の時刻の速度場から粒子の速度を 算出し，それに対しアダムス・バッシュフォース法を使い, 次の時刻の粒子位置, 及び次の時刻の粒子位置・速度場から 粒子速度を求める。

初期条件は，流れに対し適当な外乱を加えてある程度たっ たものを改めて初期条件として用いる.

\section{4. 粒子計算の模様}

計算の容易な Force monopole のみを適用したときの計算 結果の一例として，ある粒子から見たときの平面上での流線 を図 2 に示す．その時の計算条件を Table 1 に示す。粒子の 外周部を円で示している. 基準とした粒子は Figure 2 の中心 にある粒子であり，色分けは相対速度の大きさに基づいて 行っている. 粒子の上部において流線が粒子を避けている様 子が確認できる.

\section{5. 結言}

粒子の中でもマイクロバブルの付加による流体の抵抗低 減効果のような，粒子が流体の運動に影響を及ぼす結果，実 用上重要となる効果がどのような要因によって引き起こさ れるのかを調べた．粒子計算の手法として，粒子の影響を外 力に置き換えて計算する Force Coupling Method と呼ばれる
Table 1 computational condition

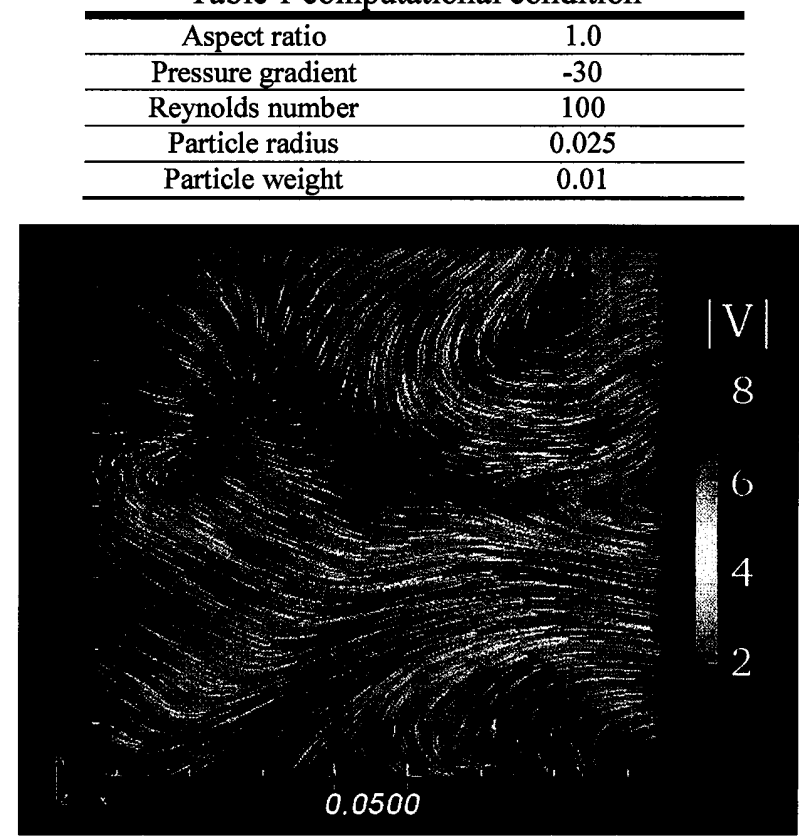

Figure 2 streamline on a plane

手法を用いた. 粒子を付加したことによる壁面せん断応力や 乱流エネルギーの変化には有意な結果は得られなかった。

今後は, 作成したプログラムを用いて矩形刊断面の縦横比 や粒子重量などを変化させ, 壁面せん断応力などとの相関関 係について調べを進めて行く.

\section{文献}

(1) M. E. McCORMICK and R. BHATTACHARYYA, "DRAG REDUCTION OF A SUBMERSIBLE HULL BY ELECTROLYSIS," Nav. Eng. J., vol. 85, no. 2, pp. 11-16, Apr. 1973.

(2) S. Lomholt, B. Stenum, and M. R. Maxey, "Experimental verification of the force coupling method for particulate flows," Int. J. Multiph. Flow, vol. 28, no. 2, pp. 225-246, Feb. 2002

(3) M. R. Maxey and B. K. Patel, "Localized force representations for particles sedimenting in Stokes flow," Int. J. Multiph. Flow, vol. 27, no. 9, pp. 16031626, Sep. 2001.

(4) S. Lomholt and M. R. Maxey, "Force-coupling method for particulate two-phase flow: Stokes flow," $J$. Comput. Phys., vol. 184, no. 2, pp. 381-405, Jan. 2003.

(5) S. L. Dance, E. Climent, and M. R. Maxey, "Collision barrier effects on the bulk flow in a random suspension," Phys. Fluids, vol. 16, no. 3, p. 828, 2004.

(6) K. Yeo and M. R. Maxey, "Simulation of concentrated suspensions using the force-coupling method," $J$. Comput. Phys., vol. 229, no. 6, pp. 2401-2421, Mar. 2010.

（7）梶島 岳夫, 乱流の数值シミュレーション. 養賢堂, 1999, pp. 69-70.

（8）牛島 省, 数值計算のための Fortran90/95 プログラ ミング入門. 森北出版, 2007, pp. 165-167. 